University of Nebraska - Lincoln

DigitalCommons@University of Nebraska - Lincoln

Faculty Publications - Textiles, Merchandising and Fashion Design

Textiles, Merchandising and Fashion Design,

Department of

January 1982

\title{
The Influence of Mordant on the Lightfastness of Yellow Natural Dyes
}

Patricia Cox Crews

University of Nebraska-Lincoln, pcrews@unl.edu

Follow this and additional works at: https://digitalcommons.unl.edu/textiles_facpub

Part of the Art and Design Commons

Crews, Patricia Cox, "The Influence of Mordant on the Lightfastness of Yellow Natural Dyes" (1982). Faculty Publications - Textiles, Merchandising and Fashion Design. 7.

https://digitalcommons.unl.edu/textiles_facpub/7

This Article is brought to you for free and open access by the Textiles, Merchandising and Fashion Design, Department of at DigitalCommons@University of Nebraska - Lincoln. It has been accepted for inclusion in Faculty Publications - Textiles, Merchandising and Fashion Design by an authorized administrator of DigitalCommons@University of Nebraska - Lincoln. 


\title{
THE INFLUENCE OF MORDANT ON THE LIGHTFASTNESS OF YELLOW NATURAL DYES
}

\author{
Patricia Cox Crews
}

\begin{abstract}
Wool specimens were premordanted with alum, chrome, copper, iron, or tin mordants and dyed with 18 yellow natural dyes. The dyed specimens were then exposed to a xenon-arc lamp for 5, 10, 20, 40, and 80 AATCC Fading Units. The color changes were evaluated instrumentally with a color difference meter and visually by trained observers. Color differences in CIE L*a*b* units, gray scale classifications, and lightfastness ratings were reported.

Turmeric, fustic, and marigold dyes faded significantly more than any of the other yellow dyes. However, dyes applied with tin and alum mordants faded significantly more than dyes mordanted with chrome, copper, or iron. In fact, mordant affected lightfastness more than dye or length of exposure. This showed that mordant was more important than dye in predicting lightfastness of colored textiles. Consequently, to make the best decisions regarding display of a textile, museum personnel should have both mordant and dye identified.
\end{abstract}

\section{INTRODUCTION}

THE USE OF NATURAL DYES to color textiles declined rapidly after the discovery of synthetic dyes in 1856, until they were virtually unused by 1900 . Consequently, the lightfastness of only a limited number of natural dyes has been evaluated by the more sophisticated fading apparatus and quantitative techniques which have been developed over the past 50 years. Yet most textiles and costumes in museum collections were colored with dyes obtained from natural sources. The lightfastness of these natural dyes must be known so that museum personnel can make proper decisions regarding the display of an artifact.

Some researchers noted this need for modern evaluation of natural dyes.1,2 However, their studies have several limitations. First, they only evaluated the lightfastness of natural dyes that were widely used industrially in European textiles. Many more dyes, particularly in the yellow range, were widely used by settlers on this continent in the eighteenth and nineteenth centuries, and by American Indians producing their various ethnic textiles.,3 Since these American textiles are of growing importance to museums, more lightfastness data are clearly needed.

Another limitation of previous studies was that they did not collect data on all five commonly used mordants - alum, chrome, copper, iron, and tin. Duff, Sinclair, and Stirling evaluated nine dyes with tin mordants primarily. ${ }^{5}$ Padfield and Landi did not evaluate chrome mordants at all; they they considered the use of chrome a modern technique because it was not in use until the early $1800 \mathrm{~s} \cdot{ }^{6,7}$ But, as discussed earlier, nineteenth-century artifacts are important to American collectors. Because previous research has these limitations, lightfastness data on natural dyes are still rather scanty.

The objectives of this study were to evaluate the lightfastness of selected yellow dyes and to evaluate the effects of commonly used mordants on the lightfastness of the dyes. I selected plants which are widely available across the United States and likely to have been used by the home dyer in Colonial America, by the American Indians, and by the contemporary fiber artist. ${ }^{8,9}$ By knowing the relative lightfastness of the yellow dyes, museum personnel could make display decisions and recommendations based on the least lightfast dye in the textile. This is usually the yellow dye.

I evaluated the effects of all commonly used mordants on color because all have been in use since the mid-1800s and most have been in use for centuries. ${ }^{10} \mathrm{I}$ also 
assessed all mordants because contemporary fiber artists premordant with all five mordants so that they can get five shades from a single dyebath. By assessing the mordants used today as well as in the past, I hoped that results of this study would be useful in conservation and display decisions for contemporary textiles, as well as for historical textiles.

\section{EXPERIMENTAL PROCEDURE}

\section{Sample Preparation}

The fabric selected for this research was $100 \%$ worsted wool flannel, Style No. 525, manufactured by Testfabrics, Inc. ${ }^{11}$ It was a $2 \times 2$ twill weave and weighed 196 $\mathrm{g} / \mathrm{m} 2$. The wool samples were scoured in a $0.5 \%$ solution of Ivory soap prior to mordanting and dyeing procedures.

The methods described by Hummel were generally used in the mordanting process. ${ }^{12}$ Quantities of the mordants and other agents used in the mordanting baths are given in Table I. Wool samples, weighing $454 \mathrm{~g}$ each, were mordanted at the boil for one hour, except for the samples with iron, which were treated for 30 minutes.

\section{TABLE I}

MORDANTING AGENTS

\begin{tabular}{clc}
\hline \hline Common Name & \multicolumn{1}{c}{ Components } & Quantity \\
\hline Alum & Aluminum potassium sulfate & $87.0 \mathrm{~g}$ \\
& Potassium bitartrate & $29.0 \mathrm{~g}$ \\
& Distilled water & 15.01 \\
Chrome & Potassium dichromate & $14.5 \mathrm{~g}$ \\
& Potassium bitartrate & $14.5 \mathrm{~g}$ \\
Copper & Distilled water & 15.01 \\
& Cupric Sulfate & $29.0 \mathrm{~g}$ \\
Iron & Distilled water & 15.01 \\
& Ferrous sulfate & $14.5 \mathrm{~g}$ \\
\multirow{2}{*}{ Tin } & Potassium bitartrate & $29.0 \mathrm{~g}$ \\
& Distilled water & 15.01 \\
& Stannous Chloride & $14.5 \mathrm{~g}$ \\
& Potassium bitartrate & $14.5 \mathrm{~g}$ \\
& Distilled water & 15.01 \\
\hline
\end{tabular}

All dye plants were collected locally except fustic, indigo, and turmeric. The local dye plants were verified by the Kansas State University Herbarium. A list of the dye plants by common and scientific names is presented in Table II. Natural dyestuffs were extracted from the plants by soaking the plant material overnight in distilled water, then boiling for one hour, straining the dye and making up to 151 with distilled water. Ten-gram specimens of the premordanted wool were dyed in the Launder-Ometer at $95^{\circ} \mathrm{C}$ for 30 minutes in $727 \mathrm{ml}$ of the dyebath. ${ }^{13}$ 
TABLE II

YELLOW DYE PLANTS

\begin{tabular}{llr}
\hline \hline \multicolumn{1}{c}{ Common Name } & \multicolumn{1}{c}{ Scientific Name } & $\begin{array}{r}\text { Quantity } \\
\text { of Plant } \\
\text { (g/15 l) }\end{array}$ \\
\hline Coreopsis (flowers) & Coreopsis tinctoria & 908 \\
Cherry, Sour (leaves) & Prunus aerasus & 454 \\
Cherry, Choke (leaves) & Prunus virginiana & 454 \\
Clover, Sweet (flowers) & Melilotus officinalis & 908 \\
Crab Apple (leaves) & Malus sp. & 454 \\
Dock (leaves and heads) & Rumex altissimum & 908 \\
Fustic & Chlorofora tinctoria & 454 \\
Goldenrod (flowers) & Solidago canadensis L. & 908 \\
Grape (leaves) & Vitis sp. & 454 \\
Indigo & Indigofera tinctoria & 114 \\
Marigolds (flowers) & Tagetes Patula Linn. & 908 \\
Mimosa (leaves and flowers) & Albizia julibrissin Durazz. & 454 \\
Mullein (leaves and flowers) & Verbascum thapsus L. & 908 \\
Onion, Yellow (skins) & Allium cepa & 454 \\
Peach (leaves) & Prunus sp. & 454 \\
Poplar, Lombardy (leaves) & Populus nigra italica & 454 \\
Smartweed (leaves and flowers) & Polygonum coccincum & 908 \\
Turmeric & Curcuma longa & 227 \\
\hline
\end{tabular}

NOTE: Indigo is a blue dye and was included for comparison purposes. The quantity listed for indigo was the quantity of dyestuff rather than plant material.

\section{Exposure to Light}

Two wool samples were dyed with each dye and mordant combination listed in Tables I and II. A dyed wool specimen, measuring $7 \times 20.5 \mathrm{~cm}$, was cut from each sample and mounted in Atlas Fade-Ometer masks and exposed to light according to AATCC Test Method 16E-1978, Colorfastness to Light: Water-cooled Xenon-Arc Lamp, Continuous Light. ${ }^{14}$ Borosilicate inner filters and soda lime outer filter glasses surrounded the xenon-arc lamp. Blue wool standards were used to control the exposure periods as recommended by AATCC. Blue wool standards consist of a series of eight different blue-dyed wool cloths specially prepared so that each higher numbered blue wool standard is approximately twice as lightfast as the preceeding standard. ${ }^{15}$ Control of the exposure to light with blue wool standards instead of clock hours is recommended by AATCC and others to overcome the problem of variability of light source. ${ }^{16}$ The specimens were exposed to 5, 10, 20, 40 and 80 AATCC Fading Units (AFUs). After each exposure period, the dyed samples were evaluated for color change instrumentally.

\section{Instrumental Evaluation}

The color change in the exposed specimens was evaluated according to AATCC Test Method 153-1978, Color Measurement of Textiles: Instrumental. A HunterLab 
Color Difference Meter, Model D25 Signal Processor and Optical Head, with a Tektronix 31 Programmable calculator was used to measure color change. ${ }^{17}$ The instrument was calibrated with a white tile, Standard No. C2-8254. Color difference measurements were made for each specimen using a $2.54 \mathrm{~cm}$ viewing aperture with a $500 \mathrm{~g}$ load applied to each specimen for proper tensioning. The readings for both specimens representing each dye-mordant combination were averaged to yield the reported color change. The CIE L* $a^{*} b^{*}$ formula was used to calculate the color change.

\section{Visual Evaluations}

The color change was also visually assessed by three trained observers following the final exposure period according to AATCC Evaluation Procedure 1, Gray Scale for Color Change. Visual assessments were made under simulated northern sky light in a MacBeth Lablite, Model BBX-526. ${ }^{18}$ Color change was assessed visually by two methods, one based on AATCC Fading Units with Gray Scale Ratings and one based on AATCC Blue Wool Lightfastness Standards.

The AATCC Gray Scale for Color Change was used to assess the color change on the dyed wool specimens after 80 AATCC Fading Units of light exposure. AATCC defines 80 AATCC Fading Units (AFUs) as the exposure required to produce "just appreciable fading" on AATCC Blue Wool Lightfastness Standard L6, regardless of the number of machine hours required to achieve this fade. ${ }^{19}$ "Just appreciable fading" is color loss equal to a Step 4 of the Gray Scale for Color Change. ${ }^{20}$

The color change was also compared to the AATCC Blue Wool Lightfastness Standards, L2, L3, L4, L5, and L6, and the colorfastness to light of a dye was classified as directed in AATCC Test Method 16-1978, Colorfastness to Light: General Method. ${ }^{21}$

\section{Statistical Analysis}

Three-way analysis of variance was used to measure the effects of dye, mordant, length of exposure, and their interactions on instrumentally measured color change..$^{22}$ Duncan's multiple range test was used to further analyze the means of each independent variable when effects were significant at the $5 \%$ level. ${ }^{23}$

\section{RESULTS AND DISCUSSION}

\section{Instrumental Evaluation}

Statistical analysis of the instrumentally measured color changes showed that every variable-mordant, dye, and length of exposure-significantly affected the amount of color change that occurred. However, mordant affected color change more than any other variable, while dye affected color change less than any other variable (see Table III). There were significant interactions between mordant and dye, mordant and length of exposure, and dye and length of exposure. With one exception, the interactions were far less significant than main effects. Consequently, the main effects, as well as the interactions, will be discussed.

\section{Mordant}

The elemental composition of the mordant had a significant effect upon color change. The greatest amount of color change occurred with alum and tin mordants, while the least amount of color change occurred with chrome, copper, and iron 
TABLE III

ANALYSIS OF THE EFFECTS OF MORDANT, DYE, AND TIME ON COLOR CHANGE

\begin{tabular}{lcr}
\hline \hline Source & $\begin{array}{c}\text { Degrees of } \\
\text { Freedom }\end{array}$ & F Value \\
\hline Mordant (M) & 4 & $1859.51^{*}$ \\
Dye (D) & 16 & $33.28^{*}$ \\
Length of Exposure & 4 & $376.72^{*}$ \\
M D & 64 & $20.80^{*}$ \\
M L & 16 & $34.37^{*}$ \\
D L & 64 & $2.60^{*}$ \\
Error Term & 256 & \\
Total & 424 & \\
\hline
\end{tabular}

${ }^{*}$ Level of significance was greater than .0001 .

mordants. The overall color change with alum and tin mordants was at least three times larger than with any of the other mordants (see Table IV).

The range of colors produced by the same dye using different mordants was remarkable, but each mordant had an individually limited range: only alum and tin yielded bright, clear yellows; chrome produced yellow-golds or oranges; copper produced yellow-greens; while iron produced shades of brown. Dyers in the past were faced with a difficult choice-favored colors versus lightfastness. The chrome mordants offer a compromise. They provide dyeings with good lightfastness and only slightly duller yellows or gold tones than those obtained with alum or tin mordants.

TABLE IV

EFFECT OF MORDANT ON COLOR CHANGE

\begin{tabular}{lcc}
\hline \hline Mordant & $\begin{array}{c}\text { Mean Color } \\
\text { Change } \\
(\Delta \mathrm{E})\end{array}$ & $\begin{array}{c}\text { Duncan's } \\
\text { Multiple } \\
\text { Range Test* }\end{array}$ \\
\hline Copper & 1.7009 & $\mathrm{~A}$ \\
Iron & 2.4192 & $\mathrm{~B}$ \\
Chrome & 3.3525 & $\mathrm{C}$ \\
Alum & 11.9337 & $\mathrm{D}$ \\
Tin & 14.1678 & $\mathrm{E}$ \\
\hline
\end{tabular}

*Means with different letters are significantly different at the 5\% significance level.

Dye

The effect of dye on color change was far less important than the effect of mordant on color change. Indigo, the most lightfast natural dye, had the least amount of color change as expected. Indigo was used without a mordant. Consequently, its mean color change was reported, but it could not be included in the general statistical analysis because all other dyes were used with mordants (see Table V). 
TABLE V

\section{EFFECT OF DYE ON COLOR CHANGE}

\begin{tabular}{|c|c|c|c|c|c|c|c|c|c|}
\hline Dye & $\begin{array}{c}\text { Mean Color } \\
\text { Change } \\
(\Delta \mathrm{E})\end{array}$ & Dur & ncan & 's M & ulti] & ple I & Rang & Test & \\
\hline Indigo & 0.9 & & & & & & & & \\
\hline Cherry, Sour & 4.6 & A & & & & & & & \\
\hline Cherry, Choke & 4.8 & A & & & & & & & \\
\hline Mullein & 4.9 & A & B & & & & & & \\
\hline Clover & 5.3 & A & B & C & & & & & \\
\hline Peach & 5.6 & & B & C & D & & & & \\
\hline Coreopsis & 5.8 & & & $\mathrm{C}$ & $\mathrm{D}$ & E & & & \\
\hline Smartweed & 6.1 & & & & $\mathrm{D}$ & $\mathrm{E}$ & & & \\
\hline Grape & 6.3 & & & & $\mathrm{D}$ & $\mathrm{E}$ & & & \\
\hline Dock & 6.6 & & & & & $\mathrm{E}$ & $\mathrm{F}$ & & \\
\hline Onion & 7.1 & & & & & & $\mathrm{~F}$ & G & \\
\hline Goldenrod & 7.3 & & & & & & & G & \\
\hline Poplar & 7.4 & & & & & & & G & \\
\hline Mimosa & 7.4 & & & & & & & G & \\
\hline Crab Apple & 7.7 & & & & & & & G & \\
\hline Marigolds & 8.5 & & & & & & & $\mathrm{H}$ & \\
\hline Fustic & 9.0 & & & & & & & & I \\
\hline Turmeric & 9.3 & & & & & & & & I \\
\hline
\end{tabular}

${ }^{*}$ Means with the same letter are not significantly different at the $5 \%$ level.

Indigo and turmeric were included in the study for comparison purposes. Indigo was noted for its good lightfastness, while turmeric was noted for its poor lightfastness. Fustic, which had a somewhat better colorfastness reputation than turmeric, was not significantly different from turmeric in amount of overall color change.

Fustic, marigolds, and turmeric had the greatest amount of overall color change. They were also the dyes that produced the brightest yellow colors and were the dyes most widely used by industry. ${ }^{24}$ The cherry leaves produced some of the most fast dyes, but the yellows were very pale by contrast. Comparison of the colors produced by the most lightfast versus the least lightfast dyes makes it clear why the least fast dyes continued in use; the bright, rich yellows by fustic and turmeric were not found with any other dye.

Length of Exposure

Length of exposure, of course, had a significant effect upon the amount of color change. To determine how length of exposure affected color, a regression analysis was conducted. Regression analysis measures rate of change and determines whether the change is linear, quadratic or some other type of trend. A significant linear trend would indicate that the amount of color change was proportional to the length of exposure, while a quadratic trend would indicate that there was a faster rate of change during some parts of exposure. Regression analysis of color change over length of exposure for the dyes in this study showed that nearly all effects of length of 
exposure on color change were linear. However, the quadratic effect was also significant because there was a slightly faster rate of change for the first exposure period (see Table VI).

TABLE VI

EFFECT OF TIME ON COLOR CHANGE

\begin{tabular}{ccc}
\hline \hline $\begin{array}{l}\text { Exposure } \\
(\text { AFUs) }\end{array}$ & $\begin{array}{c}\text { Mean Color } \\
\text { Change } \\
(\Delta \mathrm{E})\end{array}$ & $\begin{array}{c}\text { Duncan's } \\
\text { Multiple } \\
\text { Range Test** }\end{array}$ \\
\hline 5 & 3.5582 & $\mathrm{~A}$ \\
10 & 4.9709 & $\mathrm{~B}$ \\
20 & 6.5605 & $\mathrm{C}$ \\
40 & 8.2204 & $\mathrm{D}$ \\
80 & 10.2641 & $\mathrm{E}$ \\
\hline
\end{tabular}

*AATCC Fading Units.

${ }^{*}$ Means with the same letter are not significantly different.

\section{Mordant X Dye}

The interaction of the mordants with the dyes was significant, as shown in Table III. This means that the effect of mordant on dye depended to a certain extent upon which dye was used. However, further analysis of the interactions showed that the main effect of mordant was of overwhelming importance compared to the interactions of mordant with dye. In other words, the greatest amounts of color change were attributed to alum and tin mordants and the least amount of color change occurred with chrome, copper, and iron mordants as indicated by the significant main effects. In fact, every dye had the most color change when used with an alum or tin mordant, as shown in Figure 1. However, when comparing all dyemordant combinations, there was one dye (choke cherry) with an alum mordant that had less color change than three dyes with chrome mordants (see Figure 2), yet even choke cherry followed the general trend of having the most color change when it was mordanted with alum or tin.

The interaction of dyes with mordants was not simple. As a result, general trends attributable to dyes could not be easily discerned because dyes with the greatest amount of color change did not always have the greatest amount of color change with each individual mordant. For example, fustic had the second largest color change of any dye with a tin mordant, while it had the least color change of any dye with copper and iron mordants (see Figure 2). Turmeric was another example of inconsistent color changes. Turmeric with a tin mordant had the most color change of any dye-mordant combination. However, turmeric with an alum mordant had only a moderate amount of color change. These inconsistencies in amount of color change for some dyes could explain some contradictory reports in the literature regarding the lightfastness of fustic. ${ }^{25}$ When chrome mordants came into use making a more lightfast yellow color possible with fustic, its improved lightfastness was no doubt noted, yet its poor colorfastness with alum and tin mordants had been reported for many years.

Analysis of individual dye-mordant combinations showed other dyes with large amounts of overall color change but individual dye-mordant combinations with 


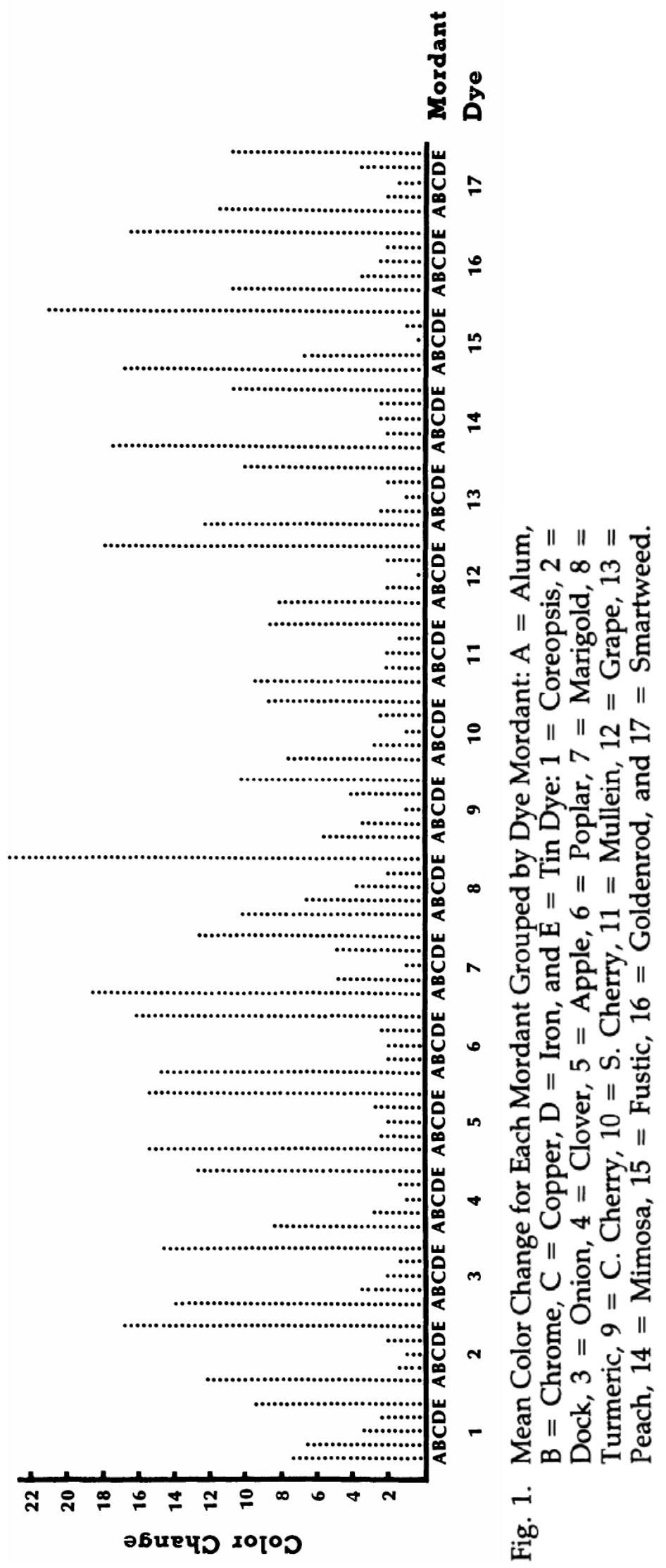




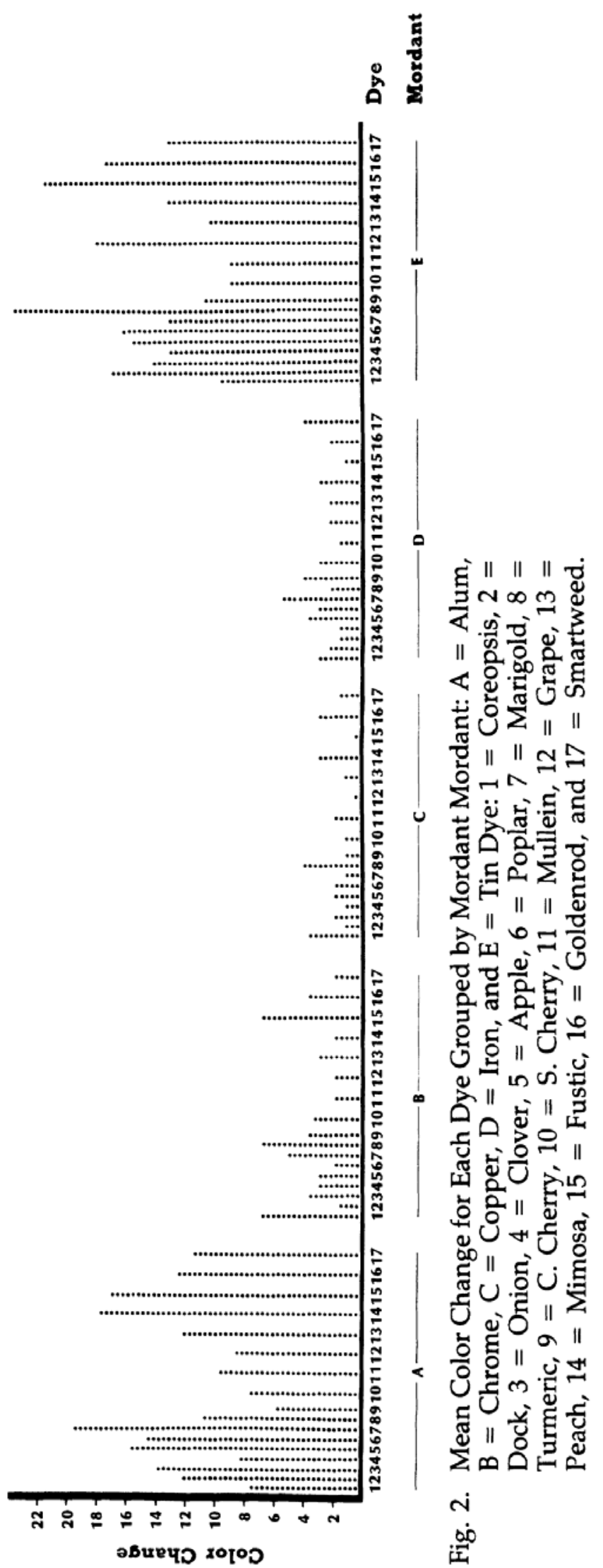


very little color change, just like fustic. This emphasizes, once again, the greater importance of mordant on lightfastness than dye.

\section{Mordant Relative to Length of Exposure}

The effect of additional amounts of exposure to light on color change depended upon which mordant was used. A regression analysis, which measured the rate of color change that occurred with additional exposure, was conducted. It showed that the color change associated with each mordant was primarily linear, that is the color change was usually proportional to length of exposure. However, the rate of color was not the same for all mordants. The rate of color change was much faster with alum and tin mordants than for chrome, copper, and iron mordants. In fact, the tin mordant had a slope, $B=.1557$, which was five times larger than the slope with the copper mordant, B = .0319 (see Figure 3). This showed that dyes used with tin mordants faded five times faster than dyes used with copper mordants.

\section{Dye Relative to Length of Exposure}

The interaction of dye with length of exposure was also significant, indicating that the effect of additional amounts of exposure to light depended upon which dye was used. It was, however, the least significant interaction with an F value of only 2.60 (see Table III). Regression analysis showed that the rate of color change for each dye was usually proportional to the length of exposure. However, some dyes faded at a faster rate than other dyes. The slopes, which indicate the rate of color change over

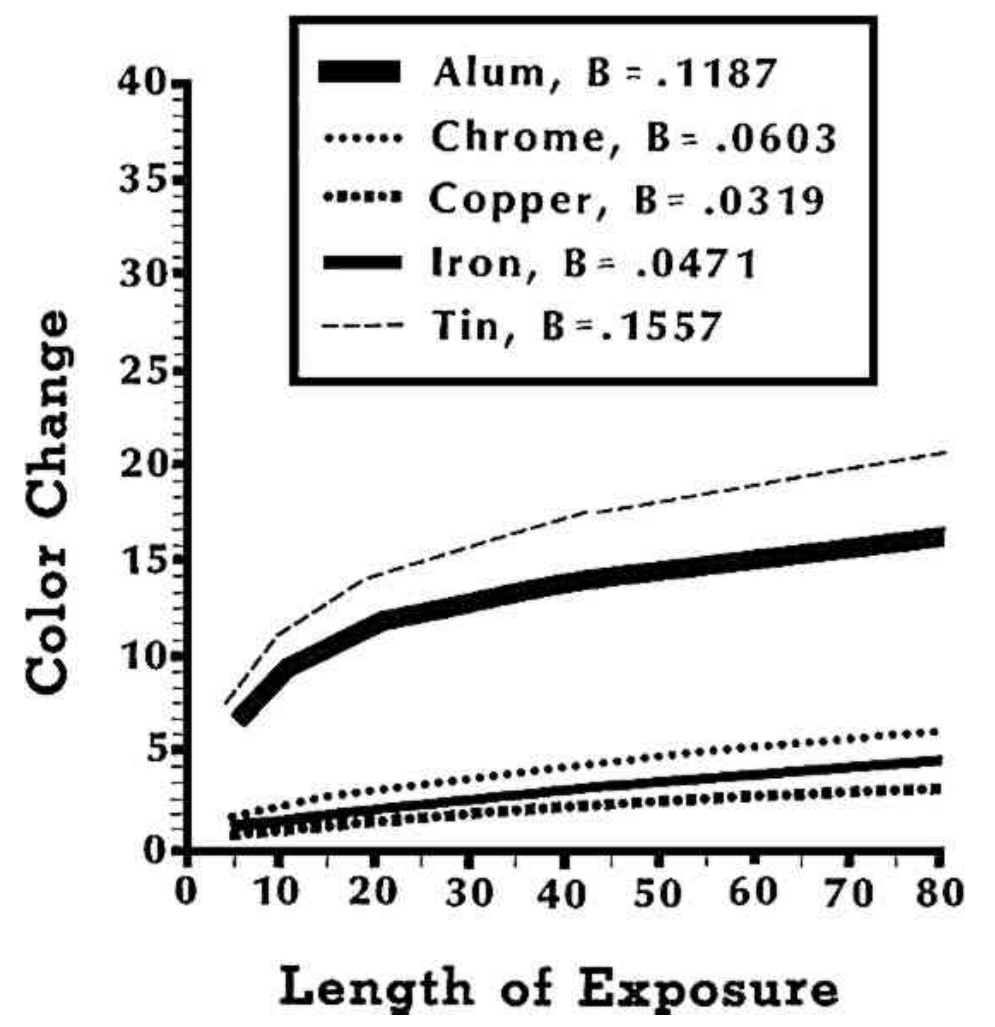

Fig. 3. Color Change as a Function of Length of Exposure by Mordant. 
time, ranged from as low as .0476 to as high as .1447 for turmeric (see Table VII). A flatter slope or a smaller B value would indicate a gradual color change over length of exposure, while a steeper slope or a larger B value would indicate a very rapid color change. Turmeric's slope was 3-4 times larger than dock, smartweed, cherry leaves, mullein, or grape leaves, which indicates that turmeric would fade four times faster than some of the other dyes mentioned.

TABLE VII

REGRESSION ANALYSIS OF COLOR CHANGE ON LENGTH OF EXPOSURE FOR EACH DYE

\begin{tabular}{lc}
\hline \hline Dye & Slope, B \\
\hline Smartweed & .0476 \\
Grape & .0509 \\
Cherry, Sour & .0537 \\
Mullein & .0551 \\
Cherry, Choke & .0586 \\
Dock & .0596 \\
Clover & .0616 \\
Peach & .0784 \\
Poplar & .0839 \\
Mimosa & .0878 \\
Crab Apple & .0924 \\
Coreopsis & .0945 \\
Onion & .0956 \\
Fustic & .0999 \\
Goldenrod & .1104 \\
Marigold & .1232 \\
Turmeric & .1447 \\
\hline
\end{tabular}

\section{VISUAL EVALUATIONS}

\section{Gray Scale Classifications}

A gray scale consists of pairs of gray chips in gradations of color differences from 1 to 5 . Gray scale ratings are made by comparing the dyed specimens to the scale under standard lighting and the classification or rating is determined by that pair of gray chips on the scale which show a contrast equal to that between the original dyed specimen and the exposed specimen. ${ }^{26}$ The gray scale classifications for all dyemordant combinations are shown in Table VIII. The gray scale classifications of the three observers did not vary from each other more than one step on the Gray Scale for Color Change. Consequently, the average gray scale classifications reported in Table VIII are representative.

Color changes are dramatic: a class 1 occurred only with tin and alum mordants. Fustic with a chrome mordant was rated class 4 and with copper and iron mordants was rated a class 5, no change. In fact, it was the only dye rated a class 5 with any mordant. Yet the colorfastness of fustic with an alum or tin mordant after exposure to 80 AFUs was only class 2.5 and class 2 , respectively. These gray scale evaluations 


\section{TABLE VIII}

\section{COLOR CHANGES AFTER EXPOSURE TO XENON LAMP FOR 80 AFUs}

\begin{tabular}{|c|c|c|c|c|}
\hline Dye & Mordant $^{1}$ & $\Delta \mathrm{E}$ & Lightfastness $^{2}$ & Gray Scale $^{3}$ \\
\hline \multirow[t]{5}{*}{ Cherry, Sour } & $\mathrm{Al}$ & 7.3 & $\mathrm{~L} 2$ & 1.5 \\
\hline & $\mathrm{Cr}$ & 2.9 & L3 & 2 \\
\hline & $\mathrm{Cu}$ & 1.2 & L5 & 3.5 \\
\hline & $\mathrm{Fe}$ & 2.7 & $\mathrm{~L} 4$ & 3 \\
\hline & Sn & 9.0 & L3 & 2.5 \\
\hline \multirow[t]{5}{*}{ Cherry, Choke } & $\mathrm{Al}$ & 5.3 & L3 & 2 \\
\hline & $\mathrm{Cr}$ & 3.7 & $\mathrm{~L} 4$ & 2 \\
\hline & $\mathrm{Cu}$ & 0.9 & L5 & 3.5 \\
\hline & $\mathrm{Fe}$ & 3.7 & $\mathrm{~L} 4$ & 2 \\
\hline & Sn & 10.4 & $\mathrm{~L} 4$ & 2.5 \\
\hline \multirow[t]{5}{*}{ Clover, Sweet } & $\mathrm{Al}$ & 8.5 & $\mathrm{~L} 4$ & 2 \\
\hline & $\mathrm{Cr}$ & 2.4 & $\mathrm{~L} 4$ & 3 \\
\hline & $\mathrm{Cu}$ & 0.8 & L6 & 4 \\
\hline & $\mathrm{Fe}$ & 1.4 & L5 & 3 \\
\hline & Sn & 13.1 & L3 & 1.5 \\
\hline \multirow[t]{5}{*}{ Coreopsis } & $\mathrm{Al}$ & 7.6 & $\mathrm{~L} 2$ & 1.5 \\
\hline & $\mathrm{Cr}$ & 6.3 & L3 & 1.5 \\
\hline & $\mathrm{Cu}$ & 3.3 & $\mathrm{~L} 4$ & 2 \\
\hline & $\mathrm{Fe}$ & 2.4 & $\mathrm{~L} 4$ & 2.5 \\
\hline & Sn & 9.3 & $\mathrm{~L} 2$ & 1.5 \\
\hline \multirow[t]{5}{*}{ Crab Apple } & $\mathrm{Al}$ & 15.5 & $\mathrm{~L} 2$ & 1.5 \\
\hline & $\mathrm{Cr}$ & 2.5 & $\mathrm{~L} 4$ & 2 \\
\hline & $\mathrm{Cu}$ & 1.9 & $\mathrm{~L} 4$ & 2 \\
\hline & $\mathrm{Fe}$ & 2.9 & $\mathrm{~L} 4$ & 2 \\
\hline & Sn & 15.7 & L3 & 1 \\
\hline \multirow[t]{5}{*}{ Dock } & $\mathrm{Al}$ & 11.8 & L3 & 1.5 \\
\hline & $\mathrm{Cr}$ & 1.5 & L5 & 3.5 \\
\hline & $\mathrm{Cu}$ & 1.0 & L5 & 3 \\
\hline & $\mathrm{Fe}$ & 2.0 & $\mathrm{~L} 4$ & 2.5 \\
\hline & Sn & 16.4 & $\mathrm{~L} 2$ & 1.5 \\
\hline \multirow[t]{5}{*}{ Fustic } & $\mathrm{Al}$ & 16.7 & L3 & 2 \\
\hline & $\mathrm{Cr}$ & 6.3 & L6 & 4 \\
\hline & $\mathrm{Cu}$ & 0.3 & L7 & 5 \\
\hline & $\mathrm{Fe}$ & 0.7 & L7 & 5 \\
\hline & Sn & 20.9 & L2 & 2 \\
\hline \multirow[t]{5}{*}{ Goldenrod } & $\mathrm{Al}$ & 12.5 & L3 & 2 \\
\hline & $\mathrm{Cr}$ & 3.3 & L5 & 3 \\
\hline & $\mathrm{Cu}$ & 2.3 & L5 & 3.5 \\
\hline & $\mathrm{Fe}$ & 2.1 & L5 & 2.5 \\
\hline & Sn & 16.4 & L3 & 1.5 \\
\hline
\end{tabular}




\begin{tabular}{|c|c|c|c|c|}
\hline \multirow[t]{5}{*}{ Grape } & $\mathrm{Al}$ & 8.7 & L2 & 1. \\
\hline & $\mathrm{Cr}$ & 2.1 & L6 & 4 \\
\hline & $\mathrm{Cu}$ & 0.6 & L7 & 4.5 \\
\hline & $\mathrm{Fe}$ & 1.8 & L5 & 3.5 \\
\hline & Sn & 18.1 & L2 & 1 \\
\hline \multirow[t]{5}{*}{ Marigolds } & $\mathrm{Al}$ & 18.9 & L2 & 1.5 \\
\hline & $\mathrm{Cr}$ & 4.8 & L4 & 2.5 \\
\hline & $\mathrm{Cu}$ & 0.9 & L5 & 3.5 \\
\hline & $\mathrm{Fe}$ & 4.7 & L3 & 1.5 \\
\hline & Sn & 13.0 & L3 & 1 \\
\hline \multirow[t]{5}{*}{ Mimosa } & $\mathrm{Al}$ & 17.5 & L2 & 1.5 \\
\hline & $\mathrm{Cr}$ & 2.1 & L6 & 4 \\
\hline & $\mathrm{Cu}$ & 2.5 & L5 & 3 \\
\hline & $\mathrm{Fe}$ & 2.3 & L4 & 2 \\
\hline & Sn & 12.4 & L5 & 3 \\
\hline \multirow[t]{5}{*}{ Mullein } & $\mathrm{Al}$ & 9.7 & L3 & 2 \\
\hline & $\mathrm{Cr}$ & 2.2 & L5 & 3.5 \\
\hline & $\mathrm{Cu}$ & 1.9 & L5 & 4 \\
\hline & $\mathrm{Fe}$ & 1.7 & L5 & 3.5 \\
\hline & Sn & 9.2 & L4 & 2.5 \\
\hline \multirow[t]{5}{*}{ Onion } & $\mathrm{Al}$ & 13.9 & L3 & 1.5 \\
\hline & $\mathrm{Cr}$ & 3.5 & L4 & 1.5 \\
\hline & $\mathrm{Cu}$ & 2.2 & L5 & 3.5 \\
\hline & $\mathrm{Fe}$ & 1.7 & L5 & 3 \\
\hline & Sn & 14.3 & $\mathrm{~L} 2$ & 1.5 \\
\hline \multirow[t]{5}{*}{ Peach } & $\mathrm{Al}$ & 11.8 & L4 & 2 \\
\hline & $\mathrm{Cr}$ & 2.5 & L4 & 3 \\
\hline & $\mathrm{Cu}$ & 1.0 & L5 & 3 \\
\hline & $\mathrm{Fe}$ & 2.1 & L4 & 2.5 \\
\hline & Sn & 10.3 & L4 & 2.5 \\
\hline \multirow[t]{5}{*}{ Poplar } & $\mathrm{Al}$ & 14.4 & L2 & 1.5 \\
\hline & $\mathrm{Cr}$ & 2.1 & L4 & 2.5 \\
\hline & $\mathrm{Cu}$ & 1.7 & L5 & 3 \\
\hline & $\mathrm{Fe}$ & 2.7 & L4 & 1.5 \\
\hline & Sn & 15.8 & L3 & 1.5 \\
\hline \multirow[t]{5}{*}{ Smartweed } & $\mathrm{Al}$ & 11.4 & L2 & 2 \\
\hline & $\mathrm{Cr}$ & 1.7 & L4 & 2.5 \\
\hline & $\mathrm{Cu}$ & 1.5 & L6 & 4 \\
\hline & $\mathrm{Fe}$ & 3.3 & L4 & 2.5 \\
\hline & Sn & 12.3 & L2 & 1.5 \\
\hline
\end{tabular}

${ }^{1} \mathrm{Al}=$ Alum; $\mathrm{Cr}=$ Chrome; $\mathrm{Cu}=$ Copper $; \mathrm{Fe}=\mathrm{Iron} ; \mathrm{Sn}=\mathrm{Tin}$.

${ }^{2} \mathrm{~A}$ rating of $\mathrm{L} 1=$ very poor; $\mathrm{L} 9=$ superlative.

${ }^{3}$ A class 1 = much changed; class 5 = negligible or no change. 
TABLE VIII-Continued

\begin{tabular}{|c|c|c|c|c|}
\hline Dye & Mordant $^{1}$ & $\Delta \mathrm{E}$ & Lightfastness $^{2}$ & Gray Scale 3 \\
\hline \multirow[t]{5}{*}{ Turmeric } & $\mathrm{Al}$ & 10.6 & L3 & 1 \\
\hline & $\mathrm{Cr}$ & 6.4 & L3 & 1.5 \\
\hline & $\mathrm{Cu}$ & 4.0 & L4 & 1.5 \\
\hline & $\mathrm{Fe}$ & 2.1 & L5 & 3 \\
\hline & Sn & 23.5 & L2 & 1 \\
\hline Indigo & None & 0.9 & L6 & 4 \\
\hline
\end{tabular}

${ }^{1} \mathrm{Al}=$ Alum; $\mathrm{Cr}=$ Chrome; $\mathrm{Cu}=$ Copper; $\mathrm{Fe}=\mathrm{Iron} ; \mathrm{Sn}=\mathrm{Tin}$.

${ }^{2}$ A rating of $\mathrm{L} 1=$ very poor; $\mathrm{L} 9=$ superlative.

${ }^{3}$ A class 1 = much changed; class 5 = negligible or no change.

illustrated, once again, some of the reasons for contradictory reports in the literature about the lightfastness of fustic.

The visual assessments of color change corresponded fairly well with instrumental measurements. However, there were some dye-mordant combinations visually assigned to the same class which had 10-15 units difference in instrumentally measured color changes. For example, following exposure to 80 AFUs, mimosa with copper and tin mordants was assigned to class 3, yet the color change measured instrumentally was only 2.5 units for mimosa with a copper mordant, while the color change was 12.4 units for mimosa with a tin mordant. Onion, peach, and turmeric were other dyes which were visually assigned to the same classes, but which had large differences in instrumentally measured color changes.

These discrepancies illustrate the problems inherent in attempts to compare and correlate visual and instrumental measurements of color changes. Human perception of color change is often different than that reflected by instrumental measurement of color change. At present, there are no color-difference equations that will yield numerical values for color differences of the same size as those perceived by the eye for all colors. ${ }^{27}$ This is the major criticism of color difference formulas and for this reason the American Association of Textile Chemists and Colorists recommends visual evaluation. ${ }^{28}$ Nevertheless, many researchers in textile mills and laboratories successfully use instrumental methods for measuring color difference. Consequently, I decided to use both types of measurements in this study despite the problems with the comparison of data.

\section{Lightfastness Ratings}

Another way to assess lightfastness of textiles is by exposing dyed specimens with blue wool standards, L1-L8. The lightfastness rating is determined by ascertaining which of the blue wool standards has faded to the same extent as the dyed specimen. ${ }^{29}$ The lightfastness ratings for all dye-mordant combinations are shown in Table VIII. Fustic with copper and iron mordants had lightfastness ratings of L7, and they were the only dye-mordant combinations above L6. Only fustic $(\mathrm{Cr})$, grape $(\mathrm{Cr})$, mimosa $(\mathrm{Cr})$, clover $(\mathrm{Cu})$, smartweed $(\mathrm{Cu})$, and indigo had lightfastness ratings of L6. These ratings show the superiority of chrome, copper, and iron mordants in producing lightfast colors. The lightfastness ratings had deviations from the instrumental measurements similar to those described for the gray scale classifications. Some dye- 
mordant combinations given the same ratings had as much as 10 units difference in instrumentally measured color changes.

\section{CONCLUSIONS}

MOST OF THE DYES tested in this study had only poor to moderate lightfastness. Many of the yellow dyes faded appreciably with exposure to as little as 5 AFUs and most yellow dyes had lightfastness ratings below L5 on a scale of L1 to L9. The dyes, fustic and turmeric, that had the greatest amounts of color change were the natural dyes most widely used in the European dye houses of the 18th and 19th centuries. ${ }^{30,} 31$ Consequently, conservators need not fear that North American textiles dyed with local plant materials will be less lightfast than textiles dyed industrially in the dye houses of that time. In fact, home-dyed and ethnic textiles may be more lightfast.

All of the dyes which had large amounts of color change were used with alum or tin mordants. Many dyes which had very little color change with chrome, copper, and iron mordants had large amounts of color change with alum and tin mordants. The effects of mordant on lightfastness have been known for some time in the textile industry, ${ }^{32}$ which is why chrome mordants are the only ones currently in use industrially. ${ }^{33}$ This work dramatically reinforces the importance of considering and carefully selecting a mordant. In fact, identification of the mordant present in a textile could be more important than dye identification in predicting lightfastness. To make the wisest display decisions, museum personnel should ideally know both dye and mordant present in the artifact.

Finally, museums should request or encourage the use of chrome, copper, and, iron mordants when making special purchases of tapestries and wall hangings for their collections from contemporary fiber artists. In this way, museums would begin practicing "preventive conservation". While the copper and iron mordants produce only yellow-green and brown shades, the chrome mordants do provide dyeings with good lightfastness and only slightly duller yellows and golds than alum or tin mordants.

\section{REFERENCES}

1 Tim Padfield and Sheila Landi, "The Light-fastness of the Natural Dyes," Studies in Conservation11 (1966), pp. 181-193.

2 David G. Duff, Roy S. Sinclair, and David Stirling, "Light-Induced Colour Changes of Natural Dyes," Studies in Conservation22 (1977), pp. 161-169.

3 Rita J. Adrosko, Natural Dyes and Home Dyeing, (New York: Dover Publications, Inc., 1971), pp. 34-39.

4 Nonabah G. Bryan, Navajo Native Dyes: Their Preparation and Use, (Palmer Lake, Colorado: The Filter Press, 1978), pp. 19-74.

5 Duff, Sinclair, and Stirling, "Light-Induced Colour Changes," pp. 161, 164.

6 Padfield and Landi, "Light-fastness," p. 189.

7 Adrosko, Natural Dyes, p. 35.

8 ibid., pp. 34-39.

9 Bryan, Navajo Native Dyes, pp. 19-74.

10 C. L. Bird, The Theory and Practice of Wool Dyeing, 4th Ed., (Yorkshire, England: The Society of Dyers and Colourists, 1972), p. 111.

11 Testfabrics, Inc., P.O. Drawer 0, 200 Blackford Ave., Middlesex, NJ 08846.

12 J. J. Hummel, The Dyeing of Textile Fabrics, 3rd Ed., (London: Cassell \& Co., Ltd., 1888), pp. 156-224. 
13 A Launder-Ometer may be obtained from Atlas Electric Devices Co., $4114 \mathrm{~N}$. Ravenswood Ave., Chicago, Illinois 60613.

14 American Association of Textile Chemists and Colorists, 1978 Technical Manual, (Research Triangle Park, North Carolina: AATCC), pp. 154-156.

15 ibid., p. 144.

16 Charles Giles and Robert McKay, "The Lightfastness of Dyes: A Review," Textile Research Journal July (1963), p. 528.

17 A HunterLab Color Difference Meter may be obtained from Hunter Associates Laboratory, Inc., 11495 Sunset Hills Road, Reston, VA 22090.

18 A MacBeth Lablite may be obtained from MacBeth Daylighting Corp., Newburgh, NY.

19 AATCC, 1978 Technical Manual, p. 142.

20 Ibid., p. 142.

21 Ibid., pp. 142-144.

22 George W. Snedecor and William G. Cochran, Statistical Methods, (Ames, Iowa: The Iowa State University Press, 1980), pp. 215-254.

23 Ibid., p. 233.

24 The Society of Dyers and Colourists, Colour Index, 3rd Ed., (Yorkshire, England: The Society of Dyers and Colourists, 1971), pp. 3225, 3227, 3229.

25 Adrosko, Natural Dyes, pp. 31-32.

26 E. R. Trotman, Dyeing and Chemical Technology of Fibers, (London: Charles Griffin \& Co., 1975), pp. 617-618.

27 E. I. Sterns, "Management of Color and Color Differences," Textile Chemist and Colorist6 (1974), pp. 71-77.

28 Ibid., p. 75.

29 Trotman, Dyeing, p. 619.

30 Clement Bolton, "Contributions to the History of Dyeing," The Dyer and Textile Printer28 (1937), p. 483.

31 Clement Bolton, "Contributions to the History of Dyeing," The Dyer and Textile Printer29 (1938), pp. 166, 213.

32 Bird, Wool Dyeing, p. 111.

33 Ibid., p. 111.

\section{ACKNOWLEDGEMENTS}

I GRATEFUlLy ACKNOWLEDGE the assistance of Dr. Barbara M. Regan, Associate Professor of Textiles, Kansas State University in the experimental design and instrumental evaluations for this study, and Dr. H. C. Fryer, Professor Emeritus of Statistics, Kansas State University in data analysis and interpretation for this paper.

Reprinted from Journal of the American Institute for Conservation 21 (1982), pp. 43-58 Copyright (C) 1982 American Institute for Conservation of Historic and Artistic Works 